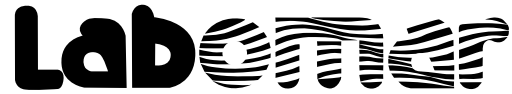

Arquivos de Ciências do Mar

\section{LENGTH-WEIGHT RELATIONSHIP OF THE SPINNER SHARK (Carcharhinus brevipinna) ON THE CONTINENTAL SHELF OF SOUTHERN BRAZIL}

\author{
Relação peso-comprimento do tubarão rotador \\ (Carcharhinus brevipinna) na plataforma continental do sul do Brasil
}

\author{
Paulo Roberto Santos dos Santos ${ }^{1 *}$, Prianka Santoro², Luiza de David Chelotti ${ }^{2}$ \\ 1 Pesquisador colaborador - Laboratório de Fisiologia de Peixes (UFSM), \\ Av Roraima n¹000, Camobi, Santa Maria, RS. *prs.dossantos@gmail.com. \\ ${ }^{2}$ Graduação em Ciências Biológicas - Laboratório de Fisiologia de Peixes (UFSM), \\ Av Roraima ${ }^{\circ} 1000$, Camobi, Santa Maria, RS.
}

\begin{abstract}
Here we present the weight-length relationship of the spinner shark (Carcharhinus brevipinna) on the continental shelf of southern Brazil, estimated from an analysis of 125 specimens. No significant differences between males and females, so the data were grouped in equation $W=0,003 L^{3.1534}$. The results presented here are the first to approach sharks above $75 \mathrm{~cm}$ and confirm the positive allometric growth of the species.
\end{abstract}

Keywords: Allometric growth, Morphometric relationship, Shark fishing, Shark nursery.

\section{RESUMO}

Aqui apresentamos, a relação peso-comprimento do tubarão-rotador (Carcharhinus brevipinna) na plataforma continental do sul do Brasil, estimada a partir de análise de 125 exemplares. Não houve diferenças significativas entre machos e fêmeas, portanto os dados foram agrupados na equação $\mathrm{W}=0,003 \mathrm{~L}^{3.1534}$. Os resultados aqui apresentados são os primeiros a abordarem tubarões acima de $75 \mathrm{~cm}$ e confirmam o crescimento alométrico positivo da espécie.

Palavras-chave: Berçário de tubarões, Crescimento alométrico, Pesca de tubarões, Relações morfométricas.

Recebido em: 30/6/2017

Aprovado em: 3/9/2017

Publicado online em: 20/1/2018 


\section{INTRODUCTION}

Studies of length-weight relationships are widely used to produce information about biology of various species, helping in the analysis of growth rates, by length or weight increase, of a species or stage of development (Kohler et al., 1996). In turn, this information is fundamental for fisheries yield studies (Wang et al., 2012).

The spinner-shark, Carcharhinus brevipinna is a coastal pelagic species, inhabitant of warm-temperate, subtropical and tropical areas (Compagno, 1984). It has a worldwide distribution occurring in the Atlantic, Mediterranean, Red Sea, Indian and Western Pacific Oceans (Garrick, 1982). In the South Atlantic, it is common in south eastern and southern coast of Brazil and frequently caught by its artisanal fishery in summer months (Gadig, 2001). Despite this, there are few studies on these populations and their biology is poorly known (Vooren \& Klippel, 2005). This work provides length-weight relationship data aiming to contribute to the knowledge of the species.

\section{MATERIALS AND METHODS}

The sharks were captured by the artisanal and industrial fleet of gill nets from the port of Rio Grande, between latitudes $29^{\circ}$ and $34^{\circ} \mathrm{S}$. Sampling occurred on nine fishing trips, between October 2014 and July 2016. All fish were, sexed, weighted (W - Kg), with a precision balance $(0.05 \mathrm{Kg})$, and measured in total length $(\mathrm{L}-\mathrm{cm})$ - maximum distance between the extremity of the muzzle and caudal fin, in the natural position. The relationships $\mathrm{W}$-L were calculated using the equation $\mathrm{W}=\mathrm{aL}^{\mathrm{b}}$, where $a$ is the intercept on the $Y$ axis of the regression curve and $b$ is the regression coefficient (Ricker, 1975). To test for possible differences between sexes, the estimated regressions were compared by a Covariance Analysis (ANCOVA, with L as covariate).

\section{RESULTS}

A total of 125 fishes were sampled, of which 69 were females $(28.0-157.0 \mathrm{~cm} / 0.1$ $23.0 \mathrm{Kg})$ and 56 were males $(32.5-148.0 \mathrm{~cm} / 0.1-16.5 \mathrm{Kg})$. No significant differences were found between males and females $(F=0.561, p=0.455)$, therefore, the way that data were grouped and the final equation was: $\mathrm{W}=0.003 \mathrm{~L}^{3.1534}$ (Table 1 ).

Table 1 - Estimated parameters of length-weight of the spinner shark Carcharhinus brevipinna, on the continental shelf of southern Brazil.

\begin{tabular}{lllllll}
\hline & $\mathrm{n}$ & $\mathrm{A}$ & CI 95\% a & $\mathrm{b}$ & CI 95\% b & $\mathrm{r}^{2}$ \\
\hline W-L & 125 & 0.003 & $0.0025-0.0039$ & 3.1534 & $2.8752-3.2007$ & 0.9881 \\
\hline
\end{tabular}

$n$, number of samples; $a$ and $b$, parameters of the equation; $\mathrm{Cl} 95 \%$, confidence limits; $\mathrm{r}^{2}$, coefficient of determination.

\section{DISCUSSION}

The continental shelf of southern Brazil may be a nursery area for C. brevipinna, because both sharks captured in this study and by Galina (2006) are neonates or juveniles, with smaller length than the suggested first sexual maturation size by Jeng Joung et al. (2005), which raises the importance of the study. The calculated values of $a$ and $b$ are estimated to be within the expected range and next of values found by Galina (2006) $(\mathrm{a}=$ $\left.0.002 ; b=3.2004 ; r^{2}=07416\right)$, for 75 fishes, concluding that the species has positive allometric 
growth, with a greater gain in weight than in length (Casselman, 1990). The larger number of sharks captured in this study may explain the higher value of $\mathrm{r}^{2}$.

\section{REFERENCES}

Casselman, J. M. Growth and relative size of calcified structures of fish. T. Am. Fish. Soc. v. 119, n. 4, p. 673-688, 1990.

Compagno, L. V. J. An annotated and illustrated catalogue of sharks species known to date. Part 2. Carcharhiniformes. FAO Fish. Synopsis, v. 125, p. 251-655, 1984.

Gadig, O. B. F. Tubarões da costa brasileira. Tese de Doutorado, Programa de Pós Graduação em Ciências Biológicas, Universidade Estadual Paulista Júlio de Mesquita Filho, 343 p., Rio Claro, 2001.

Galina, A. B. A Distribuição espacial e a composição das capturas de elasmobrânquios pela frota de emalhe de Passo de Torres-SC, na costa sul do Brasil, no verão de 2004/2005. Dissertação de Mestrado, Programa de Pós-Graduação em Oceanografia Biológica, 66 p., Rio Grande, 2006.

Garrick, J. A. F. Sharks of the genus Carcharhinus. NOAA Technical Report, 34, 194 p., 1962.

Kohler, N. E., Casey, J. G. \& Turner, P. A. Length-Length and Length-Weight Relationships for 13 Shark Species from the Western North Atlantic. NOAA Technic. Memorand. NMFS, v. 110, p. 1-22, 1996.

Ricker, W. E. Computation and interpretation of biological statistics of fish populations. $B$. Fish. Res. Board Can., v. 191, p. 1-382, 1975.

Vooren, C. M., \& Klippel, S. Ações para a conservação de tubarões e raias no sul do Brasil. Editora FURG, 246 p., Rio Grande, 2005.

Wang, T. H. S.; Wang, G. W.; Sun, D. \& Huang, J. H. Length-weight and length-length relationships for some Yangtze River fishes in Tian-e-zhou Oxbow, China. J. Appl. Ichthyol., v. 28, n. 4, p. 660-662, 2012. 
